\title{
Experimental Consideration of Projectile Density and Hardness Effect on Its Penetration Ability in Alumina Target
}

\author{
Abdul Basyir ${ }^{1}$, Romie Oktovianus Bura ${ }^{2,3 *}$ and Denny Lesmana ${ }^{4}$
}

\begin{abstract}
The development of body armour technology must be balanced with the development of ammunition technology. One of the technologies that can be undertaken to improve the performance of ammunition is to use material which is high density and high hardness in the core of the projectile, such as tungsten carbide - cobalt material (WC - 8Co). This research will analyse regarding the effects of material substitution from the Pindad's standard steel core projectile to WC - 8Co core projectile on the performance of $5.56 \times 45$ calibre ammunition on ceramic material target, alumina $\left(\mathrm{Al}_{2} \mathrm{O}_{3}\right)$. This study used experimental method by performing ballistic tests. The results showed that for $\mathrm{Al}_{2} \mathrm{O}_{3}$ material target, projectile of WC - 8Co core produced (a) 1.2 times a depth of penetration greater than Pindad's standard steel core projectile, (b) 2.1 times diameter of the crater bigger than Pindad's standard steel core projectile, and (c) 1.1 times damage deeper than Pindad's standard steel core projectile. These results showed that for $\mathrm{Al}_{2} \mathrm{O}_{3}$ material target, the performance of projectile penetration using WC - 8Co core was better than the performance of projectile penetration using the Pindad's standard steel core.
\end{abstract}

Key Words: Depth of Penetration, WC-8Co, Pindad's Standard Steel, Alumina

\section{INTRODUCTION}

One of the defence technologies which developed was body armour technology such as ceramic body armour technology (CBA). This CBA technology has been used by US military forces since 2001 in the Afghanistan War and the Iraq War [1]. In this war, CBA technology was able to reduce the threat of small arms from enemies of US military forces. CBA technology used ceramic material plates as the main material for composing body armour. Ceramic material is preferred as body armour because it is lighter by not reducing the robustness of the body armour. The lightweight and sturdy properties of this body armour are due to the properties of ceramic materials that have low density, high hardness, and high compressive strength. Alumina was one type of ceramic material used as personal body armour, beside silicon carbide and boron carbide. Mechanical property of alumina was below than silicon carbide and boron carbide, but alumina cheaper than theirs.

The development of the body armour technology needs to be balanced with the development of projectile technology. This is needed to increase the crippling power and/or lethal power of a ammunition against a target. One of the efforts made was the development of projectile technology using tungsten carbide (WC) material as the core of the projectile. Along with its development, the core material of the WC was then combined with Cobalt $(\mathrm{Co})$ material to increase the hardness and strength property of the WC material [2], so that it becomes WC - Co. Based on this, an experiment will be conducted with a ballistic test to analyse the penetration effects produced by the Pindad's standard steel core projectile with the WC - Co core projectile.

\section{METHODOLOGY}

This research was carried out by the experimental method proposed in STANAG 4241 regarding the procedure for impact testing of bullet ammunition. The experiment was carried out using ballistic test equipment. The ammunition used was the NATO standard $5.56 \mathrm{~mm} \times 45$ mm M855 / SS109 ammunition [3], specifically SS109 ammunition produced by PT. Pindad (Persero). The geometry of the ammunition can be seen in Fig. 1.

Manuscript received June 19, 2019; Accepted June 24, 2019. (ID No. jdaat-2019-00006)

${ }^{*}$ Corresponding Author: Romie Oktovianus Bura, Faculty of Defense Technology, Indonesia Defense University, IPSC Area, Bogor and 16810, Indonesia.

E-mail: romiebura@idu.ac.id, Tel.0812 19588063

${ }^{1}$ Research Center for Physics, Indonesian Institute of Sciences, PUSPIPTEK Area, Serpong and 15314, Indonesia

${ }^{2}$ Faculty of Defense Technology, Indonesia Defense University, IPSC Area, Bogor and 16810, Indonesia

${ }^{3}$ Faculty of Mechanical and Aerospace Engineering, Bandung Institute of Technology, Ganesha 10, Bandung and 40132, Indonesia

${ }^{4}$ Ammunition Division, PT. Pindad (Persero), Turen, Malang and 65175, Indonesia 


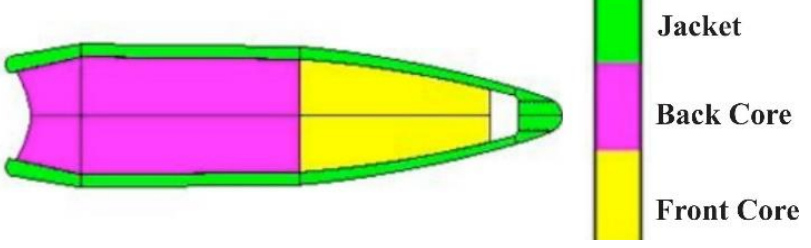

Fig. 1. Components of projectile [4].

The front core of the projectile from SS109 $5.56 \mathrm{~mm} \times$ $45 \mathrm{~mm}$ ammunition produced by PT. Pindad (Persero) was using Pindad's standard steel material. The material from the front core of the projectile will then be substituted with a tungsten carbide-cobalt material, so this study was using two types of projectiles, namely projectiles with the front core in the form of tungsten carbide-cobalt material (WC $8 \mathrm{Co}$ ) and projectiles with the front core in the form of Pindad's standard steel material. Other components of ammunition such as the back core of the projectile, jacket, casing, primer, and propellant type are made the same with the components was using by SS109 ammunition produced by PT. Pindad (Persero). This is to ensure that the penetration differences resulting from the ammunition were caused by material properties at the front core of the projectile.

The target material used was alumina $\left(\mathrm{Al}_{2} \mathrm{O}_{3}\right)$ with a size of $50 \mathrm{~mm} \times 50 \mathrm{~mm} \times 10 \mathrm{~mm}$ (length $\times$ width $\times$ thick). The target material is placed at a distance of 50 meters from the ballistic test equipment. On the back of the target material was placing a backing material in the form of plasticine (clay) with a thickness of $150 \mathrm{~mm}$. The distance between the target material and the backing material is $100 \mathrm{~mm}$ (see in Fig. 2). The backing material serves to capture the depth of penetration (DoP) and the diameter of crater produced by projectile penetration against the target.

The experimental procedure of this study consists of five stages: (1) assembly and preparation of projectiles, (2) assembly and preparation ammunitions, (3) assembly and preparation target, (4) assembly and preparation target on a frame target, and (5) ballistic test. Ballistic test stages include: (a) conditioning of barrel test, (b) determine the shooting distance between ballistic test equipment and the target position by considering accuracy and safety, (c) taking accuracy shots on the lesan paper to get the firing point produced by the projectile, (d) taking shots of target one by

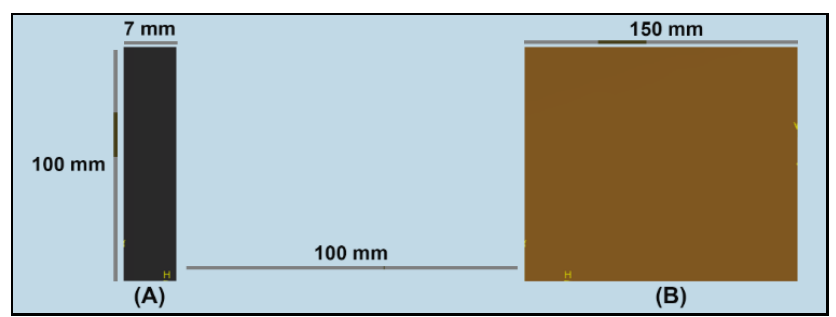

Fig. 2. Configuration view between target material (a) and backing material (b) (Drawing by Researcher, 2018). one, (e) taking measurements and/or calculations of the value of impact velocity and impact kinetic energy, and (f) measuring, observing, and recording the ballistic terminal parameters produced due to projectile penetration against the target was DoP parameters, crater diameter, mass residuals of projectiles and targets [5].

\section{RESULT AND DISCUSSION}

Data obtained from shootings of the $\mathrm{Al}_{2} \mathrm{O}_{3}$ target material use the Pindad's standard steel core projectile and WC - 8Co core projectile can be seen in Table 1 and Table 2. From Table 1, it is known that the impact velocity value generated by the WC - 8 Co core projectile is $876.95 \mathrm{~m} . \mathrm{s}^{-1}$, while the impact velocity valued generated by the Pindad's standard steel core projectile is $892.63 \mathrm{~m} . \mathrm{s}^{-1}$. The data shows that the impact velocity value generated by the Pindad's standard steel core projectile is 1.02 times greater than the impact velocity value generated by the WC - 8Co core projectile.

The average value of impact kinetic energy generated by the WC - 8Co core projectile is 1,730.43 Joule; while the average value of impact kinetic energy generated by Pindad's standard steel core projectile is 1,593.69 Joule. This data show that impact kinetic energy value generated by WC - 8Co core projectile is 1.1 times greater than impact kinetic energy value generated by the Pindad's standard steel.

The physical property of the WC - 8Co material shows that density of this material is $14,800 \mathrm{~kg} \cdot \mathrm{m}^{3}$, while the density of the Pindad standard steel material is $7,830 \mathrm{~kg} \cdot \mathrm{m}^{-3}$. This information indicates that the WC - 8Co material more tight compare to the Pindad's standard steel material, so that even though size of volume from the front core of two projectile is same, but mass of these projectile is different. Due to density of the WC - 8Co material greater than the Pindad's standard steel material, so the impact kinetic energy value produced by the WC - 8Co core projectile is greater than the impact kinetic energy value produced by the Pindad's standard steel core projectile, but the impact velocity value produced by the WC core projectile - 8Co is smaller than the impact velocity value produced by the Pindad's standard steel core projectile. This is because, in kinetic energy equations, density (mass) is inversely proportional to velocity.

From Table 2, it is known that WC - 8Co core projectiles generated an average DoP value is $53.12 \mathrm{~mm}$, while the Pindad's standard steel core projectiles produced average DoP is only $44.28 \mathrm{~mm}$. This data shows that WC - 8Co core projectiles produced DoP is 1.2 times greater than the Pindad's standard steel core projectile. Although WC - 8Co core projectiles produced average impact velocity lower than Pindad's standard steel core projectile (see Table 1), but WC - 
Table 1. Velocity and impact kinetic energy data from firing of WC - 8Co core projectiles and Pindad's standard steel core projectile again target material, alumina $\left(\mathrm{Al}_{2} \mathrm{O}_{3}\right)$

\begin{tabular}{|c|c|c|c|c|c|c|c|}
\hline \multirow{2}{*}{$\begin{array}{l}\text { Shoot dis- } \\
\text { tance }\end{array}$} & \multirow{2}{*}{$\begin{array}{c}\text { Projectile } \\
\text { type }\end{array}$} & \multirow{2}{*}{$\begin{array}{l}\text { Sample } \\
\text { number }\end{array}$} & \multicolumn{2}{|c|}{ MASS before impact (gr) } & \multicolumn{2}{|c|}{ Velocity $(\mathrm{m} / \mathrm{s})$} & \multirow{2}{*}{$\begin{array}{c}\text { EK - Impact } \\
\text { (Joule) } \\
\text { at } 50 \text { metre }\end{array}$} \\
\hline & & & $\begin{array}{l}\text { Projectile } \\
\quad( \pm 1)\end{array}$ & $\begin{array}{l}\text { Target } \\
( \pm 2)\end{array}$ & v0 & $\begin{array}{c}\mathrm{v} \text {-impact } \\
\text { (at } 50 \text { metre) }\end{array}$ & \\
\hline \multirow{12}{*}{50 metre } & \multirow{6}{*}{$\begin{array}{c}\mathrm{WC}-8 \mathrm{Co} \\
\text { core }\end{array}$} & 1 & 4.5 & 274 & 932.66 & 884.69 & $1,761.00$ \\
\hline & & 2 & 4.5 & 274 & 921.19 & 875.01 & $1,722.70$ \\
\hline & & 3 & 4.5 & 274 & 926.14 & 871.16 & $1,707.60$ \\
\hline & & Minimum & & & 921.19 & 871.16 & $1,707.60$ \\
\hline & & Maximum & & & 932.66 & 884.69 & $1,761.00$ \\
\hline & & Mean & & & 926.66 & 876.95 & $1,730.43$ \\
\hline & \multirow{6}{*}{$\begin{array}{c}\text { Pindad's } \\
\text { standard } \\
\text { steel core }\end{array}$} & 1 & 4.0 & 274 & 948.58 & 897.67 & $1,611.62$ \\
\hline & & 2 & 4.0 & 274 & 950.81 & 898.57 & $1,614.86$ \\
\hline & & 3 & 4.0 & 274 & 932.78 & 881.64 & $1,554.58$ \\
\hline & & Minimum & & & 932.78 & 881.64 & $1,554.58$ \\
\hline & & Maximum & & & 950.81 & 898.57 & $1,614.86$ \\
\hline & & Mean & & & 944.06 & 892.63 & $1,593.69$ \\
\hline
\end{tabular}

Table 2. Depth of Penetration (DoP), diameter of crater, and residual mass of target material and projectile data after firing on material target alumina, $\mathrm{Al}_{2} \mathrm{O}_{3}$

\begin{tabular}{|c|c|c|c|c|c|c|c|c|c|}
\hline \multirow{2}{*}{$\begin{array}{l}\text { Shoot } \\
\text { distance }\end{array}$} & \multirow{2}{*}{$\begin{array}{l}\text { Projectile } \\
\text { type }\end{array}$} & \multirow{2}{*}{$\begin{array}{l}\text { Sample } \\
\text { number }\end{array}$} & \multicolumn{4}{|c|}{$\begin{array}{l}\text { DOP (PLASTICINE) }(\mathrm{mm}) \\
\text { with AIR GAP }(100 \mathrm{~mm})\end{array}$} & \multicolumn{3}{|c|}{ Diameter (mm) } \\
\hline & & & 1 & 2 & 3 & Mean & $\mathrm{X}$ & $\mathrm{Y}$ & Mean \\
\hline \multirow{12}{*}{50 metre } & \multirow{6}{*}{$\begin{array}{l}\text { WC - } 8 \mathrm{Co} \\
\text { core }\end{array}$} & 1 & 56.42 & 58.03 & 58.16 & 57.54 & 77.46 & 88.37 & 82.92 \\
\hline & & 2 & 52.00 & 52.50 & 55.00 & 53.17 & 70.00 & 71.18 & 70.59 \\
\hline & & 3 & 47.26 & 48.35 & 50.32 & 48.64 & 68.76 & 70.50 & 69.63 \\
\hline & & Minimum & 47.26 & 48.35 & 50.32 & 48.64 & 68.76 & 70.50 & 69.63 \\
\hline & & Maximum & 56.42 & 58.03 & 58.16 & $\mathbf{5 7 . 5 4}$ & 77.46 & 88.37 & 82.92 \\
\hline & & Mean & 51.89 & 52.96 & 54.49 & 53.12 & 72.07 & 76.68 & 74.38 \\
\hline & \multirow{6}{*}{$\begin{array}{l}\text { Pindad's } \\
\text { standard } \\
\text { steel core }\end{array}$} & 1 & 45.46 & 45.93 & 46.25 & 45.88 & 38.64 & 41.73 & 40.19 \\
\hline & & 2 & 40.99 & 43.89 & 45.40 & 43.43 & 34.53 & 38.98 & 36.76 \\
\hline & & 3 & 37.78 & 39.80 & 41.20 & 39.59 & 26.27 & 35.91 & 31.09 \\
\hline & & Minimum & 37.78 & 39.80 & 41.20 & 39.59 & 26.27 & 35.91 & 31.09 \\
\hline & & Maximum & 45.46 & 45.93 & 46.25 & 45.88 & 38.64 & 41.73 & 40.19 \\
\hline & & Mean & 41.41 & 43.21 & 44.28 & 42.97 & 33.15 & 38.87 & 36.01 \\
\hline
\end{tabular}

8Co core projectile can produced DoP greater than Pindad's standard steel projectile. One of the main parameters affecting the size of DoP produced by projectile penetration was the impact of kinetic energy. Fig. 3 shows that the relationship between impact kinetic energy and DoP is directly proportional. A projectile with a large impact kinetic energy will produce a DoP that also large on target, and vice versa, a projectile with a small impact kinetic energy will produce a small DoP on target.

Table 2 also shows that the crater diameter produced by penetration of the $\mathrm{WC}-8 \mathrm{Co}$ core projectile is greater than the crater diameter produced by penetration of Pindad's standard steel core projectile. The average crater diameter produced due to penetration of WC - 8Co core projectile is $74.38 \mathrm{~mm}$, while the average crater diameter produced due to penetration of the Pindad's standard steel core projectile is $36.01 \mathrm{~mm}$. The crater diameter produced by penetration of WC - 8Co core projectiles is 2.1 times greater than the diameter of crater produced by the Pindad's standard steel core projectile for target material, alumina (see Fig. 4).

The big and/or small size of the crater diameter that occurs is influenced by the number of residual projectiles that 


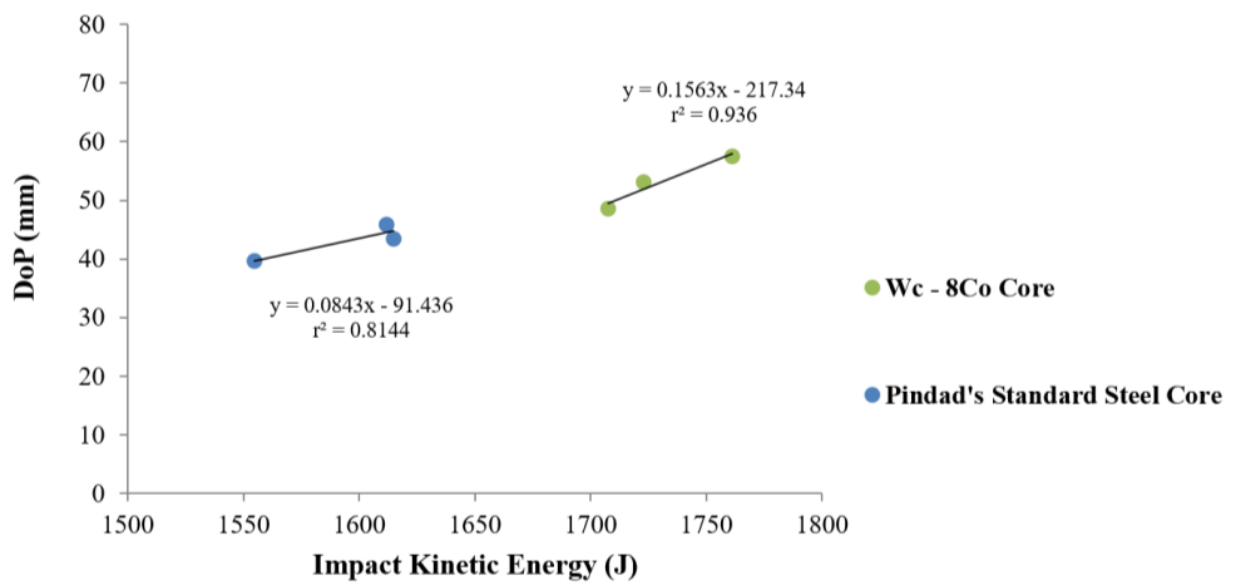

Fig. 3. Relationship between impact kinetic energy with Depth of Penetration (DoP) produced by WC - 8Co core projectile and Pindad's standard steel core projectile (Data Process by Researcher, 2018).

have successfully penetrated to the target material, alumina. The greater of crater diameter that occurs, so more distribution of residual projectile fragments that have successfully penetrate to the target material, $\mathrm{Al}_{2} \mathrm{O}_{3}$. Besides that, hardness parameter of projectile and target material also has an important role in creating size of crater diameter. The hardness of target material causes erosion and deformation to the projectile, and projectile can failure if the hardness of projectile much smaller than hardness of target material. In this experiment, the hardness of WC - 8 Co core projectiles is bigger than alumina, so WC - $8 \mathrm{Co}$ core projectile can minimize defence effect, erosion and deformation of alumina. The hardness of Pindad's standard steel core projectile is smaller than alumina, so this projectile gets much erosion and deformation effect when impact with alumina.

The big/small size of projectile residual that occurs after a collision between a projectile with a target is affected by the hardness size of the core projectile. From material property data, it is known that alumina has a higher hardness than WC - 8Co and Pindad's standard steel material. The hardness value of WC - 8Co material is greater than the Pindad's standard steel material so that WC - 8Co core projectile will be better to deal with the hardness of target material, alumina, than Pindad's standard steel. In the event of a collision between projectile and target, the component of WC - 8Co core projectile will erode less than the component of Pindad's standard steel core projectile.

Based on microstructure view (Fig. 5 and Fig. 6), we can see that damage profile on the material target after penetrating by WC - 8Co core projectile greater than by Pindad's standard steel core projectile. Value of damage peak created by WC - 8Co core projectile on the target material is $7708.79 \mu \mathrm{m}$, when damage peak value created by Pindad's standard steel core projectile on the target material is 7094.88 $\mu \mathrm{m}$. Impact kinetic energy and hardness of WC - 8Co core

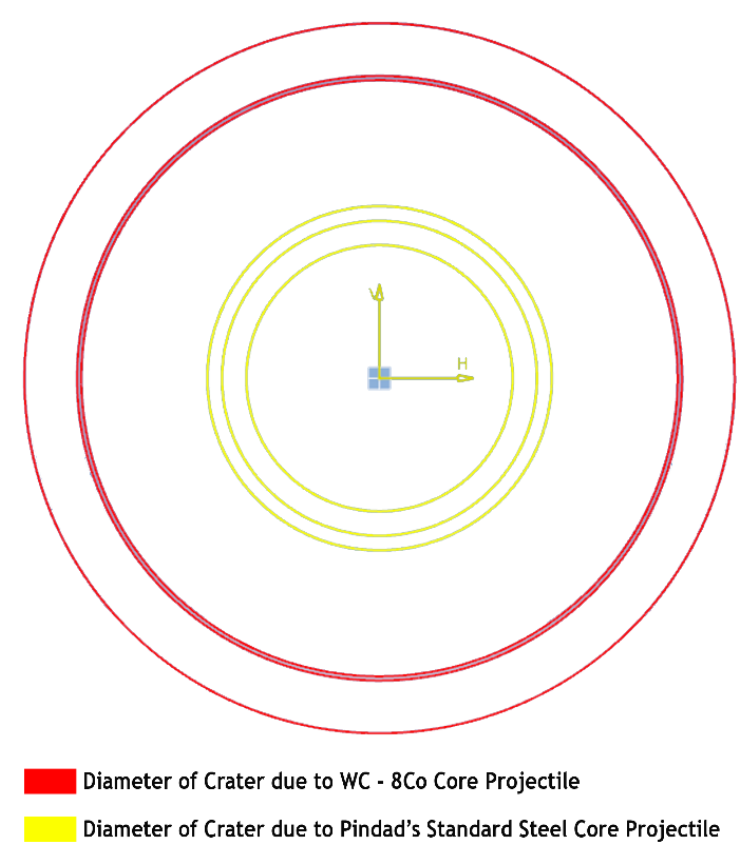

Fig. 4. Comparison of crater diameter produced by penetration of WC - 8Co core projectiles and Pindad's standard steel core projectile (Data Process by Researcher, 2018).

projectile is main parameter making big damage on the target material, where impact kinetic energy and hardness of WC - 8Co material bigger than Pindad's standard steel material. Moreover, roughness of target material after penetrating by WC - 8Co core projectile is bigger than by Pindad's standard steel core projectile. This indicates that damage area on target material by WC - 8Co core projectile is deeper and wider than Pindad's standard steel core projectile.

The depth of penetration (DoP) size, damage profile on target material, and crater diameter measured on the backing material due to penetration of the two type projectiles indicate that WC - 8Co core projectile produces a better 


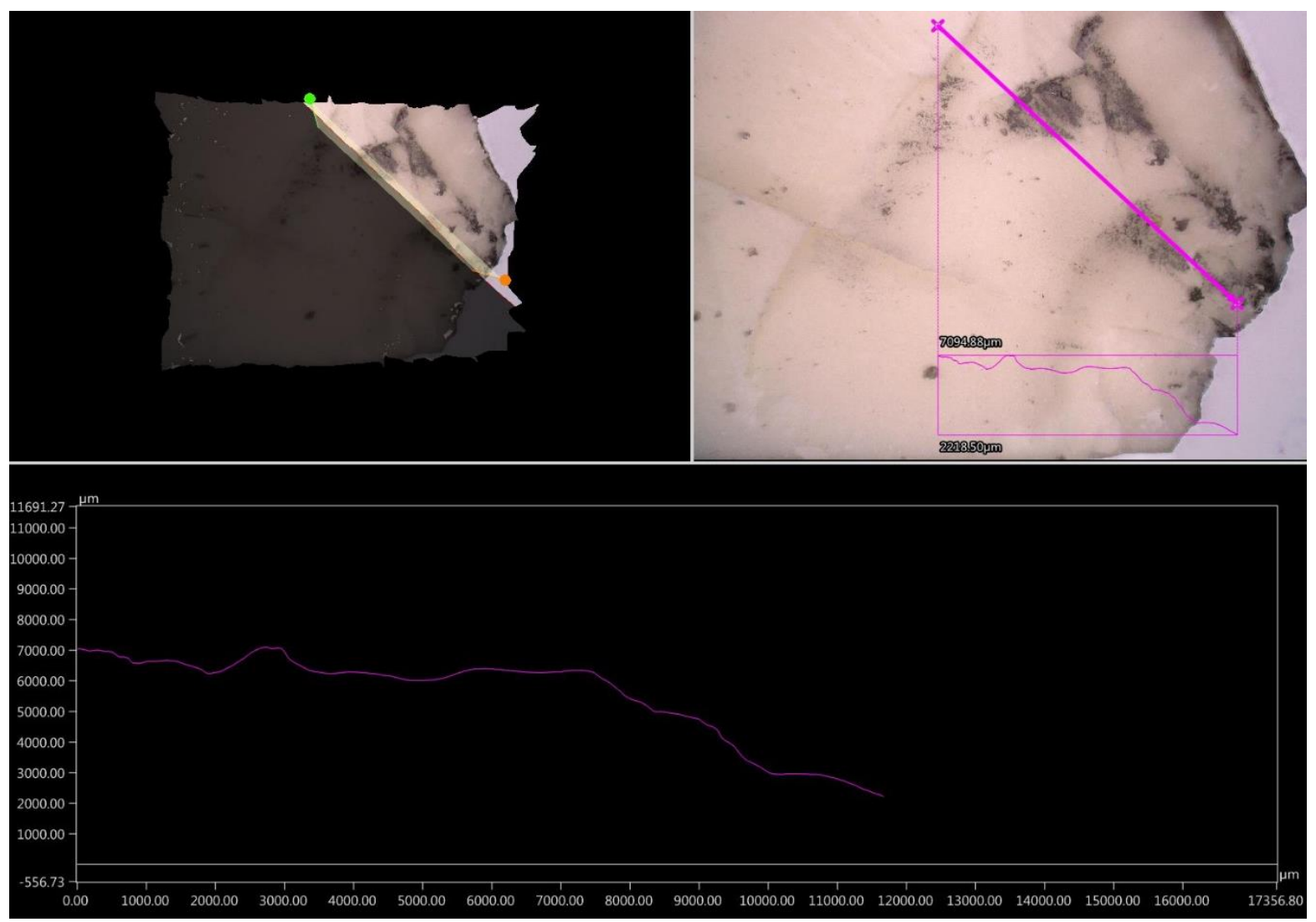

Fig. 5. Damage profile of silicon carbide (target material) after penetrating by Pindad's standard steel projectile (Data Process by Researcher, 2019).
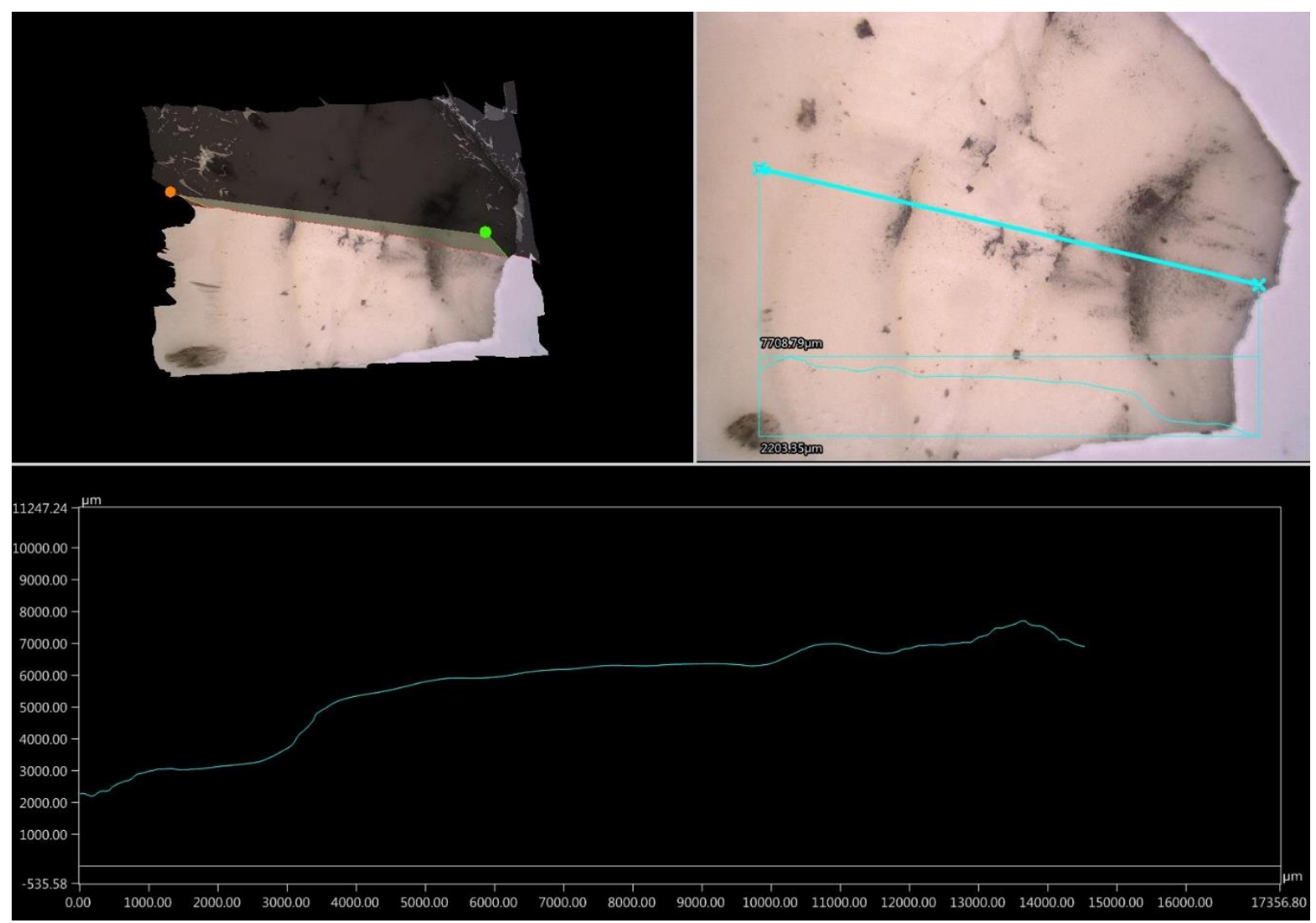

Fig. 6. Damage profile of silicon carbide (target material) after penetrating by WC - 8Co projectile (Data Process by Researcher, 2019). 
penetration on target material, alumina, than Pindad's standard steel core projectile.

\section{CONCLUSION}

The penetration performance of projectile using WC 8 Co core projectile is better than the Pindad's standard steel core projectile for target material, alumina $\left(\mathrm{Al}_{2} \mathrm{O}_{3}\right)$ :

1. WC - 8Co core projectile produced 1.2 times a depth of penetration greater than Pindad's standard steel core projectile.

2. WC - 8Co core projectile produced 2.1 times diameter of the crater bigger than Pindad's standard steel core projectile.

3. WC - 8Co core projectile produced 1.1 times a damage deeper than Pindad's standard steel core projectile.

\section{ACKNOWLEDGEMENT}

The researcher said thanks to the Indonesia Defense University, PT. Pindad (Persero), and Research Center for
Physics (Indonesian Institute of Sciences) which has facilitated tools and materials, test equipment, provides moral and fund support for the implementation of this research.

\section{REFERENCES}

[1] Lehowicz, et al. Testing of Body Armor Materials: Phase III. Washington: The National Academic Press, 2012, p.3.

[2] A. S. Kurlov and A. I Gusev, Tungsten Carbides: Structure, Properties, and Application in Hardmetals. Springer International Publishing), 2013, p.229

[3] STANAG 4172, Standardization Agreement of 5.56 Ammunition. Brussels: NATO, 1993.

[4] F. Coghe, N. Nestor, and L. Rabet. "Experimental and numerical investigations on the origins of the bodywork effect (K -Effect)," Journal of Applied Mechanics, vol. 77, no. 55, 051801, 2010, p.8.

[5] STANAG 4241, Standardization Agreement (AOP) of Bullet Impact Munition Test Procedures Edition A, Version 1. Brussels: NATO, 2018.

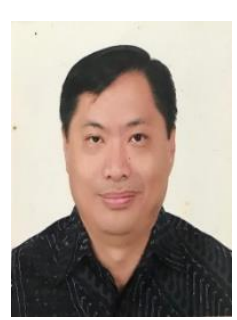

Romie Oktovianus Bura obtained his Bachelor in Engineering BEng.(Hons.) from University of Manchester Institute of Science and Technology (UMIST) and $\mathrm{PhD}$ from University of Southampton, UK, both in Aerospace Engineering. He is currently an academic member of the Faculty of Mechanical and Aerospace Engineering, Flight Physics Research Group at Bandung Institute of Technology, Indonesia. He is now the Dean of the Faculty of Defense Technology, Indonesia Defense University. His main research interest is high-speed aerodynamic, design and propulsion; shock-related fluid dynamics and hypersonic flow as well as airframe-propulsion integration. He maintains collaboration with other institution in Germany, UK and Japan in the field of high-speed flow. 


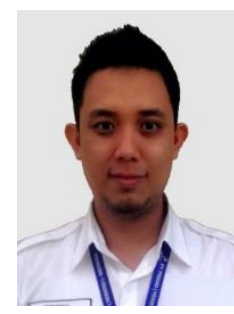

Denny Lesmana received his BSc degree (Chemistry) at Brawijaya University, Indonesia in 2010 and his MSc degrees (Defence and Security) at Cranfield University, the UK in 2018. He worked as a junior researcher and assistant manager in PT. Pindad (Persero), Turen, Indonesia from 2012 until now. He also worked as a visiting lecturer in the Polytechnic of Army Forces in Malang, Indonesia. He is currently working with ammunition process and product development. His research interests are ammunition design, warhead system, engineering simulation (CFD and Structural Analysis), fragmentation, and defeat mechanism. 